\title{
Evaluation of Readiness of the Urban Environment to the Introduction of the Concept of "Smart Transport" in the Subjects of the Russian Federation
}

\author{
Svetlana Gutman ${ }^{1 *}$, Polina Vorontsova ${ }^{1}$, Vladislav Seredin ${ }^{1}$ \\ ${ }^{1}$ Peter the Great St. Petersburg Polytechnic University, Polytechnicheskaya, 29, 195251 Saint-Petersburg, \\ Russia
}

\begin{abstract}
This article expands on the problem of implementation and assessment of the readiness to develop "Smart Transport" in the subjects of the Russian Federation. The authors used qualitative and quantitative methods to achieve the goal of this study, namely, the development of an approach to assess the level of readiness of certain territories for the potential digitalization of public transport through the introduction of the concept of "Smart Transport." As a result of the study, components of the strategic map for increasing the readiness of the analyzed subject to the implementation of the concept of "Smart Transport" in the subjects of the Russian Federation are proposed. The structure of the components is determined, and the rating scale and the basis of the indicator system for monitoring the readiness of each subject under consideration for the development of "Smart Transport" are formed, the values of which are calculated and presented in the form of an aggregate indicator of the overall assessment for eight subjects of the Russian Federation. The uniqueness of this study lies in the fact that on the basis of the analysis carried out using the fuzzy logic method, as well as the compiled system of balanced indicators, it forms an approach to the general assessment and subsequent monitoring of the level of development of the concept of "Smart Transport" in the constituent entities of the Russian Federation with proposals to increase the relevance of the aggregate indicator by introducing additional indicators that take into account modern trends and the specific features of each region under consideration and allowing making subsequent studies more qualitative. The results obtained describe in sufficient detail the current readiness of the Russian regions both for the introduction and implementation of the concept of "Smart Transport" and for the general "digitalization" of the subjects under consideration.
\end{abstract}

Keywords: Digitalization; Smart city; Smart mobility; Smart transport; Transport development

\section{Introduction}

Today, "Smart Transport" (ST), along with the development of information and communication technologies (ICTs), is being introduced worldwide at different rates. Its main objectives include improving the efficiency of the transport system, minimizing damage to the environment and existing infrastructure, and improving the characteristics of cities to attract tourists and local residents who do not use public transport. Thus, it is a complex approach to the transformation of the city, both digital and socioeconomic (Dorofeeva et al., 2019; Gutman and Vorontsova, 2020).

When planning the development of the concept of ST in the context of a dynamically

*Corresponding author's email: Gutman@spbstu.ru, Tel.: +7-9217481481

doi: 10.14716/ijtech.v12i 7.5340 
changing surrounding reality, it is vital to understand and clearly identify the readiness of each specific territorial entity to the large-scale "digital" transformations, especially in the field of ground urban passenger transport (GUPT). Therefore, the goal of this study is to develop an approach to assessing the level of readiness of certain territories for the potential digitalization of public transport through the introduction of the concept of ST.

Considering various works (Leviäkangas, 2013; Al-Nasrawi et al., 2015; Papa and Lauwers, 2015; Benevolo et al., 2016; Garau et al., 2016; Hassn et al., 2016; Mirri et al., 2016; Jeekel, 2017; Pinna et al., 2017; Docherty et al., 2018; Espinoza et al., 2018; Soriano et al., 2018; Woodhead, 2018; Sakai, 2019; Agaton et al., 2020) devoted to research in areas such as ST, "Smart Mobility," and "Mobility as a Service" (MaaS), we can conclude that in general there are two main approaches to assessing the quality and condition of ST systems: qualitative and quantitative analysis. The methods used in the study of transport phenomena are diverse both in their fields of application and in the tools employed for calculations (Leviäkangas, 2013; Garau et al., 2016; Hassn et al., 2016; Pinna et al., 2017; Espinoza et al., 2018; Agaton et al., 2020). For example, technical analysis of passenger traffic involves the use of mathematical and statistical tools to calculate the parameters existing in real life, which, due to limitations of financial, technical, and other genesis, cannot be calculated on a large scale in real time for monitoring (Hassn et al., 2016; Kulachinskaya et al., 2017; Espinoza et al., 2018; Ivanov et al., 2020). When studying Russian research works on the topic of ST, we are convinced that most of the materials that have any calculations for assessing the development of transport systems are based on foreign studies or on Russian-language analyses of foreign methodologies and the results obtained using them (Kulachinskaya et al., 2017; Kulachinskaya et al., 2018; Dorofeeva et al., 2019; Gutman and Vorontsova, 2020; Ivanov et al., 2020). This is caused by a greater degree of study of this issue by European countries (Garau et al., 2016), a number of Asian and international companies (transport development indices in cities are provided by companies such as Cisco and EasyPark), various universities (the business school of the University of Navarre publishes a report "IESE cities in motion"), and a number of governments.

There is currently no unified Russian system for assessing the status and development of ST. Partially, a compilation of a system of balanced indicators of the development of ST in the subjects of the Russian Federation can be the solution to this problem. This will allow us to systematize the existing statistical data on the transport sector and related spheres of the economy, as well as to assess the level of readiness for the introduction of digital technologies, including technologies of the ST, of the subjects of the Russian Federation. Therefore, within the framework of this study, the assessment of territories (constituent entities of the Russian Federation) in this context was carried out using the fuzzy logic method, as well as a compiled system of balanced indicators, which is a fairly new approach for a general assessment and subsequent monitoring of the level of development of the concept of ST in the constituent entities of the Russian Federation.

\section{Methods}

Qualitative and quantitative methods were chosen as the methods used to achieve the goal of this study. The qualitative methods used in this article include systematic, comparative, and content analysis and a balanced scorecard (BS) system proposed by R. Kaplan and D. Norton. Quantitative methods include methods for collecting and processing statistical information, fuzzy logic.

The BS system, proposed in Kaplan and Norton (2014), subject to its adaptation, allows us to explore issues related to the readiness of subjects to develop and implement a strategy 
for the development of the concept of ST at different levels (city, region, country), including bringing the system of indicators in accordance with the goals and strategy, which in the future will contribute to the development of ST in the Russian Federation as a whole. The application of the BS methodology allows us to form a list of targets that are designed to cover a long period of time (typical for strategic planning), allow dynamic and continuous monitoring of the state of subjects and cities of the Russian Federation to display a real and comprehensive picture of the development of ST in the country, provide an opportunity to compare the results of the activities of local authorities, and contribute to stimulating the activities of state organizations developing the concept of ST at the federal level.

Through systematic, comparative, and content analysis, we determined the composition of quantitative and qualitative indicators that characterize the readiness of the subjects of the Russian Federation under consideration for implementation of the strategy for the development of ST. Then, on the basis of the method of fuzzy logic modeling (FLM), we calculate an aggregate indicator of the level of readiness of the subject for the introduction of the concept of "smart" urban transport and provide the appropriate characteristic for the considered subjects of the Russian Federation.

In detail, the mathematical apparatus of FLM and operations on fuzzy numbers are explained by Zadeh (1975), the founder of this method, and Nedoseykin (2003), on which we rely in the course of this study. In the process of applying the fuzzy logic method, the following steps are performed (Vedernikov, 2006): (1) introduction of a linguistic variable and formation of a scale to assess the level of readiness of the subject for digitalization and the development of "smart" urban transport; (2) formation of indicators and formation of a matrix of values of factors; (3) calculation of the aggregate indicator of the level of readiness of the subject under consideration for digitalization and development of "smart" urban transport; and (4) characterization of the level of digitalization and readiness for the development of "smart" urban transport in the constituent entities of the Russian Federation on the basis of the formed scale.

\section{Results and Discussion}

The concept of ST in the Russian Federation, at the moment, does not have a common formed system for assessing its implementation and is not officially part of regular or longterm state and local development programs. Therefore, it is impossible to use any current methodology for assessing the readiness of subjects for digitalization in general and for the introduction of the concept of ST in particular. When adapting the classical BS system, it is necessary to take into account the specifics of the selected research objects. In our case, the economic entities preparing to implement the strategy are the subjects of state and municipal management, namely, city administrations, government committees, project offices at development departments, transport industrial clusters of various subjects of the Russian Federation, etc. The specificity of these subjects lies in the fact that budget funds for the implementation of a range of projects are already planned. The motivation for the development of the object of management for these public institutions is the direct order or achievement of the planned values of the target indicators set by the organization higher up in the hierarchy.

Thus, in this study, four basic components of the classical BS system (Kaplan and Norton, 2014) (Financial, Customer, Internal Business, and Innovation and Learning) were adapted in accordance with the specifics of the ST and public administration. In this manner, the "Financial" component for the subjects of the Russian Federation has been transformed into the block "Quality of Life." The "Customer" component in the proposed model is presented in the block "Environment". The components of "Internal Business" and 
"Innovation and Learning" are represented by the blocks "Digital Infrastructure" and "Science and Innovations," respectively.

In order to start creating an aggregate indicator of the subject's readiness to develop the concept of ST in the Russian Federation, we determine the most frequently mentioned or similar in purpose indicators in the previously considered studies on a given topic, including in federal open databases (in particular, in regional collections of socioeconomic development by Rosstat and individual indicators from the EMISS database). Indicators of this kind can be applied to the subjects of the Russian Federation under consideration by distributing them by enlarged spheres of management in cities according to the BS system (see Tables 1-4).

Table 1 Structure of the "Quality of Life" component

\begin{tabular}{|c|c|c|}
\hline Strategic Objective & Indicators & \\
\hline \multirow{3}{*}{$\begin{array}{l}\text { Growth of financial well- } \\
\text { being of the population }\end{array}$} & Average per capita cash income of the population (per month, RUB) & $\mathrm{X} 1$ \\
\hline & Number of own cars per 1000 people (at the end of the year, units) & X6 \\
\hline & Consumption expenditure per capita on average (per month, RUB) & \\
\hline \multirow{4}{*}{$\begin{array}{l}\text { Growth of gross regional } \\
\text { product }\end{array}$} & Gross regional product (RUB) & $\mathrm{X} 2$ \\
\hline & $\begin{array}{l}\text { Actual final consumption of households on the territory of the constituent entities of } \\
\text { the Russian Federation (at current market prices, RUB) }\end{array}$ & \\
\hline & Gross regional product per capita (RUB) & \\
\hline & Inflow of foreign direct investment in the $\mathrm{R}$ & \\
\hline \multirow{2}{*}{$\begin{array}{l}\text { Ensuring the safety of } \\
\text { the population }\end{array}$} & $\begin{array}{l}\text { Number of persons killed in road accidents in the constituent entities of the Russian } \\
\text { Federation, per } 100000 \text { population (number of persons) }\end{array}$ & $\mathrm{X} 3$ \\
\hline & Number of crimes recorded during the reporting period (number) & \\
\hline \multirow{3}{*}{$\begin{array}{l}\text { Increasing accessibility } \\
\text { of public transport }\end{array}$} & Passenger turnover of public buses (thousand pass.-km) & $\mathrm{X} 4$ \\
\hline & Number of operational public buses per 100000 population (number) & $\mathrm{X} 5$ \\
\hline & Transport infrastructure quality index compared to the 2017 level (\%) & \\
\hline
\end{tabular}

Table 2 Structure of the "Environment" component

\begin{tabular}{|c|c|}
\hline Strategic Objective & Indicators \\
\hline \multirow{3}{*}{$\begin{array}{l}\text { Transition to green } \\
\text { energy }\end{array}$} & $\begin{array}{l}\text { Share of operational buses capable of using gas as motor fuel in the total number of } \mathrm{X} 7 \\
\text { operating buses }(\%)\end{array}$ \\
\hline & Share of renewable energy production in the total volume $(\%)$ \\
\hline & Number of electric charging points (number) \\
\hline \multirow{2}{*}{$\begin{array}{l}\text { Raising the priority of } \\
\text { environmental } \\
\text { initiatives }\end{array}$} & Environmental costs (in actual prices, million RUB) \\
\hline & Emissions of pollutants into the air (thousand tons) \\
\hline \multirow{3}{*}{$\begin{array}{l}\text { Landscaping, greening of } \\
\text { cities }\end{array}$} & Total area of green spaces within the city limits (ha) \\
\hline & $\begin{array}{l}\text { Discharge of contaminated wastewater into surface water bodies (million cubic } \\
\text { meters) }\end{array}$ \\
\hline & Number of people living in adverse environmental conditions (number) \\
\hline
\end{tabular}

Table 3 Structure of the "Digital Infrastructure" component

\begin{tabular}{|c|c|c|}
\hline Strategic Objective & Indicators & \\
\hline \multirow{3}{*}{$\begin{array}{l}\text { Providing easy access } \\
\text { to telecommunications }\end{array}$} & Level of digitalization of the local telephone network in urban areas (\%) & $\mathrm{X} 10$ \\
\hline & Number of personal computers per 100 employees (number) & \\
\hline & Use of personal computers in households (\%) & \\
\hline \multirow{2}{*}{$\begin{array}{l}\text { Creating sustainable } \\
\text { IT infrastructure }\end{array}$} & $\begin{array}{l}\text { Number of active subscribers to fixed broadband Internet access per } 100 \text { people (at } \\
\text { the end of the year, units) }\end{array}$ & $\mathrm{X} 11$ \\
\hline & $\begin{array}{l}\text { Number of active subscribers to mobile broadband Internet access per } 100 \\
\text { population (at the end of the year, units) }\end{array}$ & $\mathrm{X} 12$ \\
\hline \multirow[b]{2}{*}{$\begin{array}{l}\text { Implementation of } \\
\text { ICTs in enterprises }\end{array}$} & Use of the Internet in organizations (\%) & \\
\hline & $\begin{array}{l}\text { Use of ICTs in organizations (as a percentage of the total number of surveyed } \\
\text { organizations of the relevant subject of the Russian Federation), including personal } \\
\text { computers, servers, local computer networks, and "cloud" services (\%) }\end{array}$ & $\mathrm{X} 13$ \\
\hline
\end{tabular}




\begin{tabular}{lll}
\hline \multicolumn{1}{c}{ Strategic Objective } & \multicolumn{1}{c}{ Indicators } & X14 \\
\hline & Costs for the introduction and use of digital technologies in 2019 (million RUB) & \\
\cline { 2 - 4 } & Use of digital document management in organizations (\%) & X15 \\
Increasing the level of & $\begin{array}{l}\text { Daily or almost daily use of the Internet by the population (according to a sample } \\
\text { survey of the population on the use of ICTs; as a percentage of the total population of } \\
\text { population }\end{array}$ & $\begin{array}{l}\text { Ame relevant subject of the Russian Federation) (\%) } \\
\text { therant of information transmitted when accessing the Internet, including fixed } \\
\text { access and mobile access (petabyte) }\end{array}$ \\
\hline
\end{tabular}

Table 4 Structure of the "Science and Innovations" component

\begin{tabular}{|c|c|c|}
\hline Strategic Objective & Indicators & \\
\hline \multirow{3}{*}{$\begin{array}{l}\text { Increasing the priority of } \\
\text { scientific activity (at the } \\
\text { regional level) }\end{array}$} & Internal expenditures on research and development (million RUB) & $\mathrm{X} 16$ \\
\hline & Receipt of patent applications (number) & \\
\hline & Grant of patents (number) & \\
\hline \multirow{2}{*}{$\begin{array}{l}\text { Increase in the number } \\
\text { of specialists }\end{array}$} & $\begin{array}{l}\text { Number of personnel engaged in research and development, including researchers, } \\
\text { technicians, support staff, etc. (number) }\end{array}$ & $\mathrm{X} 17$ \\
\hline & Number of researchers with academic degrees (number) & \\
\hline \multirow{4}{*}{$\begin{array}{l}\text { Improving the efficiency } \\
\text { of R\&D in the region (at } \\
\text { the enterprise level) }\end{array}$} & Expenditures on innovative activities of organizations in 2019 (million RUB) & $\mathrm{X} 18$ \\
\hline & Volume of innovative goods, works, and services (million RUB) & \\
\hline & Research and development organizations (number) & \\
\hline & Advanced production technologies used (\%) & \\
\hline
\end{tabular}

Based on the compiled list (Tables 1-4), we select 18 indicators $\left(\mathrm{X}_{\mathrm{i}}\right)$, on the basis of which an aggregate indicator for assessing the readiness of the subjects of the Russian Federation for the implementation of the concept of ST is calculated. These indicators are proposed for consideration and subsequent monitoring to obtain a dynamic picture for assessing the readiness of the constituent entities of the Russian Federation for implementation of the concept of ST.

To determine the level of readiness of the subjects of the Russian Federation for implementation of the concept of ST, we introduce the linguistic variable "the level of readiness of the subjects of the Russian Federation for implementation of the concept of ST," describing it with a set of indicators:

$$
\mathrm{Y}=[\mathrm{x} ; \mathrm{T} ; \mathrm{D}]
$$

where $\mathrm{x}$ is the name of the variable "the level of readiness of the subjects of the Russian Federation for implementation of the concept of ST"; T is the set of values "Extremely low level of readiness for implementation of the concept of ST," "Low level of readiness for implementation of the concept of ST," "Medium level of readiness for implementation of the concept of ST," "High level of readiness for implementation of the concept of ST," and "Extremely high level of readiness for implementation of the concept of ST"; and D is the domain at the segment [0;1]. The value of the function Y characterizes the level of readiness of the subjects of the Russian Federation for implementation of the concept of ST, depending on a number of selected factors. This function is called the parameter that evaluates this element. To assess the level of readiness of the subjects of the Russian Federation for implementation of the concept of ST, a scale of fuzzy values of the variable Y has been developed (see Table 5).

After mathematical transformations, that is, normalization of $\mathrm{X}_{\mathrm{i}}$ indicators, distribution of factors by subsets of the scales "extremely low" (0-0.333), "low" (0.167-0.5), "average" (0.333-0.667), "high" (0.5-0.833), and "extremely high" (0.833-1), and calculation of the levels of significance of factors, sub-indicators for each of the BS blocks were calculated, and the aggregate indicator $Y$ for the subjects of the Russian Federation for 2019 was calculated. Table 6 presents the results of the calculation of the aggregate indicator reflecting the level 
of readiness of the studied subjects of the Russian Federation to implement the concept of ST.

Table 5 Scale for assessing the level of readiness of the subject for implementation of the concept of ST (compiled by the authors)

\begin{tabular}{|c|c|c|}
\hline $\begin{array}{l}\text { Range } \\
\text { of } \\
\text { Values }\end{array}$ & Linguistic Evaluation & Transcript \\
\hline $\begin{array}{l}0- \\
0.333\end{array}$ & $\begin{array}{l}\text { Extremely low level of readiness for } \\
\text { implementation of the concept of ST in the } \\
\text { transport system of the subject of the } \\
\text { Russian Federation, more than } 50 \% \text { lower } \\
\text { than the average value for the Russian } \\
\text { Federation. }\end{array}$ & $\begin{array}{l}\text { Extremely low level of provision of the population with } \\
\text { public transport, the vast majority of which uses } \\
\text { nonenvironmentally friendly fuel (vehicles used are morally } \\
\text { and physically outdated and worn). The Internet and digital } \\
\text { technologies are practically not used by citizens. R\&D costs } \\
\text { are low or insignificant. }\end{array}$ \\
\hline $\begin{array}{l}0.167- \\
0.5\end{array}$ & $\begin{array}{l}\text { Low level of readiness for implementation } \\
\text { of the concept of ST in the transport system } \\
\text { of the subject of the Russian Federation, } \\
\text { more than } 25 \% \text { lower than the average } \\
\text { value for the Russian Federation. }\end{array}$ & $\begin{array}{l}\text { The level of development of public transport is insufficient, } \\
\text { as well as the level of use of "green" fuel. The Internet is used } \\
\text { daily by a minority of citizens. R\&D costs have a small share } \\
\text { in the budget of the subject. }\end{array}$ \\
\hline $\begin{array}{l}0.333- \\
0.667\end{array}$ & $\begin{array}{l}\text { Average level of readiness for } \\
\text { implementation of the concept of "ST in the } \\
\text { transport system of the subject of the } \\
\text { Russian Federation, at the level of the } \\
\text { average value in the Russian Federation. }\end{array}$ & $\begin{array}{l}\text { The subject is provided with public transport, a gradual } \\
\text { transition to "green" fuel is carried out. The Internet and } \\
\text { information technologies are actively used in everyday life, in } \\
\text { business, and in transport. R\&D costs are essential for the } \\
\text { development of the subject's economy. }\end{array}$ \\
\hline $\begin{array}{l}0.5- \\
0.833\end{array}$ & $\begin{array}{l}\text { High level of readiness for implementation } \\
\text { of the concept of ST in the transport system } \\
\text { of the subject of the Russian Federation, } \\
\text { more than } 25 \% \text { higher than the average } \\
\text { value for the Russian Federation. }\end{array}$ & $\begin{array}{l}\text { Environmentally friendly public transport in the region is } \\
\text { actively developing. The Internet is used by a larger portion } \\
\text { of the population in almost all spheres of life and, in } \\
\text { particular, in transport. Expenditures on innovative } \\
\text { development are in the priority of the subject's budget. }\end{array}$ \\
\hline $\begin{array}{l}0.667- \\
1\end{array}$ & $\begin{array}{l}\text { Extremely high level of readiness for } \\
\text { implementation of the concept of ST in the } \\
\text { transport system of the subject of the } \\
\text { Russian Federation, more than } 50 \% \text { higher } \\
\text { than the average value for the Russian } \\
\text { Federation. }\end{array}$ & $\begin{array}{l}\text { Public eco-friendly and "smart" transport is implemented } \\
\text { everywhere. The Internet is effectively used in all spheres of } \\
\text { the subject's life. R\&D costs are the highest in the country. }\end{array}$ \\
\hline
\end{tabular}

Table 6 The value of the aggregate indicator Y for eight subjects of the Russian Federation for 2019 (compiled by the authors)

\begin{tabular}{llll}
\hline $\begin{array}{c}\text { Subjects of the Russian } \\
\text { Federation }\end{array}$ & \multicolumn{1}{c}{ Value of Indicators } & \multicolumn{1}{c}{$\begin{array}{c}\text { Subjects of the Russian } \\
\text { Federation }\end{array}$} & Value of Indicators \\
\hline Saint Petersburg & $\mathrm{Y}=0.4344$ & Krasnodar Territory & $\mathrm{Y}=0.3540$ \\
Leningrad Region & $\mathrm{Y}=0.3195$ & Tatarstan & $\mathrm{Y}=0.4162$ \\
Moscow & $\mathrm{Y}=0.6941$ & Sverdlovsk Region & $\mathrm{Y}=0.4479$ \\
Sevastopol & $\mathrm{Y}=0.3117$ & Novosibirsk Region & $\mathrm{Y}=0.3661$ \\
\hline
\end{tabular}

The leader in terms of the value of the indicator is, naturally, Moscow, where the country's finances are concentrated and scientific and social initiatives are scaled. Also, Moscow acts as an innovator in the field of public transport in Russia, actively carrying out reforms, testing, and introducing innovations. According to the developed linguistic scale, the level of development of the subject is estimated as "high," that is, the complex level of development of Moscow is approximately 50\% higher than the national average. The outsider among the studied regions is Sevastopol, where the lowest indicator reflects the state of the research and environmental components of the region, as well as insufficiently developed provision of the population with telephone communication and the Internet. St. Petersburg can be compared in terms of development with the Sverdlovsk region, but at the 
level of sub-indicators, the regions differ: the fact that in St. Petersburg the environment is estimated below average (and in the Sverdlovsk region it is, on the contrary, higher than the national average) is compensated by the values of the sub-indicators of the "Science and Innovations" block. In general, the state of the transport system of such a city as St. Petersburg relative to the declared concepts is estimated as "average," along with the Sverdlovsk and Novosibirsk regions, the Krasnodar Territory, and the Republic of Tatarstan. Moscow, as a leader in importance, is estimated according to this methodology at the level of "above average." Lagging regions, among those studied, with values "below average" on the scale are the Leningrad Region and the city of Sevastopol.

According to the results of the study, it was determined that the aggregate level of development of the concept of ST and the readiness of the urban environment for its implementation are estimated for 2019 as the national average, along with the fact that the economy and infrastructure, for example, of St. Petersburg is technologically more advanced than other cities of Russia, obviously second only to Moscow. According to calculations, the least developed side of the city of St. Petersburg is the environmental sphere: the area of forests in the urban area, environmental costs in general, and the transition of operational buses to natural gas are estimated as below average and very low. Also, according to the methodology, the research and innovation development of the city lags behind the national average. The situation is worse with the indicator of the costs for innovative activities in enterprises. There is also a lag in the number of researchers in the city compared to the country average.

This assessment system can be improved or adjusted for specific tasks of researchers by introducing the weights of factors. Moreover, we can also supplement this system with highly specialized indicators (which are not currently published in open databases of federal statistics) for assessing the transport environment of the city (see Table 7).

Table 7 Indicators proposed for further collection and inclusion in the calculation of the aggregate indicator (compiled by the authors)

\begin{tabular}{|c|c|c|}
\hline Sphere & Strategic Objective & Indicator \\
\hline \multirow{5}{*}{ Quality of Life } & \multirow{5}{*}{$\begin{array}{l}\text { Increasing accessibility of } \\
\text { public transport }\end{array}$} & Total length of bike paths $(\mathrm{km})$ \\
\hline & & Travel time to work (minutes) \\
\hline & & Number of parking spaces in the city center (number) \\
\hline & & $\begin{array}{l}\text { Percentage of people satisfied with public transport services } \\
\text { (quality of service) }(\%)\end{array}$ \\
\hline & & Number of trips paid for by electronic means of fare payment (\%) \\
\hline Environment & $\begin{array}{l}\text { Raising the priority of } \\
\text { environmental initiatives }\end{array}$ & $\begin{array}{l}\text { Total emissions of greenhouse gases and harmful substances into } \\
\text { the atmosphere by type of substance (tons per year) }\end{array}$ \\
\hline \multirow{2}{*}{$\begin{array}{l}\text { Digital } \\
\text { Infrastructure }\end{array}$} & \multirow{2}{*}{$\begin{array}{l}\text { Implementation of ICTs in } \\
\text { transport }\end{array}$} & Number of electric vehicle charging stations (number) \\
\hline & & $\begin{array}{l}\text { Number of car sharing and sharing of services for micromobility } \\
\text { (kiksharing, bikesharing) (number) }\end{array}$ \\
\hline $\begin{array}{l}\text { Science and } \\
\text { Innovations }\end{array}$ & $\begin{array}{l}\text { Improving the efficiency of } \\
\text { R\&D in the region }\end{array}$ & $\begin{array}{l}\text { Number of registered patents and useful models in the field of } \\
\text { ICTs and transport (number) }\end{array}$ \\
\hline
\end{tabular}

Thanks to the approach proposed in the article and the developed aggregate indicator, it became possible to assess the readiness of the subjects of the Russian Federation for implementation of the concept of ST. At the same time, it is necessary to note the fact that at present, a large number of studies are devoted not to the study of the concept of ST as a separate direction, but to a systematic approach to the introduction of ST technologies in the aggregate, where ST is only part of the overall model for the digitalization of the urban 
environment and its subsequent sustainable development, as a result of which researchers determine coefficients and indicators reflecting the general readiness of the subjects under consideration to the implementation of all programs, strategies, and technologies indirectly or directly related to the concept of "Sustainable Smart City" (Al-Nasrawi et al., 2015; Dorofeeva et al., 2019; Gorodnova and Sokolov, 2021). As for the analysis of the concept of ST, for the most part, the current state of affairs is assessed and the possibilities of organizing urban logistics in accordance with the principles of "Smart Mobility" and MaaS are analyzed using appropriate digital technologies (Leviäkangas, 2013; Papa and Lauwers, 2015; Garau et al., 2016; Mirri et al., 2016; Jeekel, 2017; Pinna et al., 2017; Docherty et al., 2018; Soriano et al., 2018; Woodhead, 2018; Sakai, 2019). In other studies, the authors consider various aspects of the use of "smart" digital technologies in transport in different cities, but they do not assess the overall readiness of the considered territories (in the context of various aspects) to the introduction of these technologies on an ongoing basis in comparison with other subjects (Benevolo et al., 2016; Hassn et al., 2016; Garau et al., 2016; Kulachinskaya et al., 2017; Espinoza et al., 2018; Kulachinskaya et al., 2018; Woodhead, 2018; Agaton et al., 2020; Ivanov et al., 2020). The uniqueness of this study lies in the fact that the analysis is carried out not on the transition from "particular to general" but from "general to particular" so that the results obtained by us can either differ from other studies on similar topics, or lead to similar conclusions, but using other methods. That is, in this article, using the method of fuzzy logic, an assessment of the level of readiness of certain territories for the introduction of ST technologies without affecting all areas of development of Smart City (SC) is carried out. Our results quite accurately reflect the current state of the subjects of the Russian Federation. The results of Gorodnova and Sokolov (2021) partially coincide with our research and confirm it in the context of the leading cities in terms of the overall level of digitalization and readiness for innovation (Moscow, St. Petersburg) since the general readiness of the territories under consideration for digitalization is put at the forefront. However, they differ in the main purpose of the study, approaches to analysis, and the choice of the analyzed subjects of the Russian Federation.

\section{Conclusions}

As a result of the study, the main goal, which was to develop a system of indicators for assessing the level of readiness of a certain territory for the potential digitalization of public transport through the introduction of the concept of ST, was fully achieved. On the basis of the developed aggregate indicator, an assessment of the development of the concept of ST in some large cities of Russia was carried out for their subsequent comparison with each other. Based on the results obtained, their analysis and formulation of conclusions on the state of the subjects of the Russian Federation for 2019 were carried out. As a result of the calculations, it was found that among the studied cities, there are not any with a high level of development both for an aggregate indicator and for individual sub-indicators except Moscow, where the country's finances are concentrated and scientific and social initiatives are scaled up. Also, Moscow acts as an innovator in the public transport sector in Russia. The outsider among the studied regions is Sevastopol, where the lowest indicators reflect the state of the research and environmental areas of the region, as well as the underdeveloped provision of the population with telephone communications and the Internet. This is logically justified only by the nascent processes of digitalization, eco- and user-friendly trends, and a relatively new for Russia mechanism of complying with the principles of sustainable development. 
For further development of the system for monitoring the development of ST, additional highly specialized indicators have been proposed, designed to show a more accurate picture in the future calculation of the aggregate indicator. The results can not only form the basis of further research on a given topic but also serve as a benchmark for city authorities for the annual monitoring of the state of digitalization of each subject of the Russian Federation under consideration and its readiness for the introduction of innovative projects in the sphere of public life, including ST as one of the key factors of sustainable development of a region.

\section{Acknowledgements}

The research is funded by the Ministry of Science and Higher Education of the Russian Federation as part of World-class Research Center program: Advanced Digital Technologies (contract No. 075-15-2020-934 dated 17.11.2020).

\section{References}

Agaton, C., Collera A., Guno, Ch., 2020. Socio-Economic and Environmental Analyses of Sustainable Public Transport in the Philippines. Sustainability, Volume 12 (11), pp. 114

Al-Nasrawi, S., Adams, C., El-Zaart, A., 2015. A Conceptual Multidimensional Model for Assessing Smart Sustainable Cities. Journal of Information Systems and Technology Management, Volume 12 (3), pp. 54-558

Benevolo, C., Dameri, R.P., D’Auria, B., 2016. Smart Mobility in Smart City. Empowering Organizations. Springer. Cham, pp. 13-28

Docherty, I., Marsden, G., Anable, J., 2018. The Governance of Smart Mobility. Transportation Research Part A: Policy and Practice, Volume 115, pp. 114-125

Dorofeeva, L., Rodionov, D., Velichenkova, D., 2019. Infrastructure Potential of Creating "Smart Cities". In: Proceedings of the 2019 International SPBPU Scientific Conference on Innovations in Digital Economy

Espinoza, C., Munizaga, M., Bustos, B., Trépanier, M., 2018. Assessing the Public Transport Travel Behavior Consistency from Smart Card Data. Transportation Research Procedia, Volume 32, pp. 44-53

Garau, C., Masala, F., Pinna, F., 2016. Cagliari and Smart Urban Mobility: Analysis and Comparison. Cities, Volume 56, pp. 35-46

Gorodnova, N., Sokolov, S., 2021. Practical Implementation of the Smart City Concept in the Russian Federation: Analysis of the Current State and Prospects. Economics, Entrepreneurship and Law, Volume 11(6), pp. 1439-1456

Gutman, S., Vorontsova, P., 2020. Issues of Development of Smart Transport Assessment Indicators. In: Proceedings of the International Scientific Conference-Digital Transformation on Manufacturing, Infrastructure and Service, pp. 1-11

Hassn H.A., Ismail A., Borhan M., Syamsunur D., 2016. The Impact of Intelligent Transport System Quality: Drivers' Acceptance Perspective. International Journal of Technology, Volume 7(4), pp. 553-561

Ivanov, M., Danchenko, M., Barabanov, A., Sokolitsyn, A., 2020. Manage Traffic Flows within the City using Smart City Technologies. In: Proceedings of the International Scientific Conference - Digital Transformation on Manufacturing, Infrastructure and Service, pp. $1-7$

Jeekel, H., 2017. Social Sustainability and Smart Mobility: Exploring the Relationship. Transportation Research Procedia, Volume 25, pp. 4296-4310 
Kaplan, R., Norton, D., 2014. The Balanced Scorecard: Translating Strategy into Action. (2nd ed.) corr. and amend. / trans. from Eng. by M. Pavlova. - M.: Olimp Biznes

Kulachinskaya, A., Kravchenko, V., Bezdenezhnykh, T., 2018. Organizational Mechanisms of Allocation of Subsidies for Public Transport in St. Petersburg. In: Proceedings of the $31^{\text {st }}$ International Business Information Management Association Conference, pp. 4706- 4711

Kulachinskaya A., Kravchenko, K., Kuporov, K., 2017. Analysis of Tariff Policy in Urban Transport in St. Petersburg. In: Proceedings of the $30^{\text {th }}$ International Business Information Management Association Conference, Madrid, pp. 2096-2106

Leviäkangas P., 2013. Intelligent Transport Systems-Technological, Economic, System Performance and Market Views. International Journal of Technology, Volume 4(3), pp. 288-298

Mirri S., Prandi, C., Salomoni, P., Callegati, F., Melis, A., Prandini, M., 2016. A Service-oriented Approach to Crowdsensing for Accessible Smart Mobility Scenarios. Mobile Information Systems, Volume 2016, pp. 1-14

Nedoseykin, A.O., 2003. Methodological Bases of Modeling of Financial Activity Using FuzzyMultiple Descriptions. Russian-Language Dissertation

Papa, E., Lauwers, D., 2015. Smart Mobility: Opportunity or Threat to Innovate Places and Cities. In: The 20th International Conference on Urban Planning and Regional Development in the Information Society (REAL CORP 2015), pp. 543-550

Pinna, F., Masala, F., Garau, C., 2017. Urban Policies and Mobility Trends in Italian Smart Cities. Sustainability, Volume 9(4), pp. 1-21

Sakai, K., 2019. Maas Trends and Policy-Level Initiatives in the EU. IATSS Research, Volume 43(4), pp. 207-209

Soriano, F.R., Samper-Zapater, J.J., Martinez-Dura, J.J., Cirilo-Gimeno, R.V., Plume, J.M., 2018. Smart Mobility Trends: Open Data and Other Tools. IEEE Intelligent Transportation Systems Magazine, Volume 10(2), pp. 6-16

Vedernikov, V.V., 2006. Fuzzy-Logic Modeling in the Analysis and Forecasting of Economic Phenomena and Processes: A Historical Aspect. Problems of Modern Economics, No. 12, pp. 446-449

Woodhead, R., 2018. Building Smarter City. International Journal of Technology, Volume 9(7), pp. 1509-1517

Zadeh, L., 1975. The Concept of a Linguistic Variable and its Application to Approximate Reasoning. Information Sciences, Volume 8(3), pp. 199-249 